\title{
Memory and materiality
}

Katrina Schlunke

Memory Studies 2013 6: 253

DOI: $10.1177 / 1750698013482864$

The online version of this article can be found at:

http://mss.sagepub.com/content/6/3/253

\author{
Published by: \\ (SAGE \\ http://www.sagepublications.com
}

Additional services and information for Memory Studies can be found at:

Email Alerts: http://mss.sagepub.com/cgi/alerts

Subscriptions: http://mss.sagepub.com/subscriptions

Reprints: http://www.sagepub.com/journalsReprints.nav

Permissions: http://www.sagepub.com/journalsPermissions.nav

Citations: http://mss.sagepub.com/content/6/3/253.refs.html

>> Version of Record - Jun 28, 2013

What is This? 


\section{Memory and materiality}

\author{
Katrina Schlunke
}

University of Technology, Sydney, Australia
Memory Studies 6(3) 253-261

(c) The Author(s) 2013

Reprints and permissions: sagepub.co.uk/journalsPermissions.nav DOI: $10.1177 / 1750698013482864$ mss.sagepub.com

@SAGE

\begin{abstract}
This article explores the idea of memory effects, that is, memory and materiality as intertwined producers of something we can call memory effects. This article argues that memory is an 'effect' produced through and with materiality, rather than something only produced by a human-centred consciousness. Through an exploration of the scale of memory in the shapes of a tiny Captain Cook painted on a matchbox and a giant Captain Cook, which stands as 'Big Cook' in Cairns in northern Queensland (Australia), new paths of perception and connection that may better account for the circulations and translations of memory are established. To think of memory as having a scale is to see memory as always simultaneously physical and temporal. These are memory effects. To think memory as memory effects is to give memory a key place not just in orders of concatenating events that we may over-determine as 'national' but as an order of perception given to us by the things themselves.
\end{abstract}

\title{
Keywords
}

Captain Cook, effects, materiality

We take things for granted; we use them; we rely on things. Our consciousness is a very small percentage of our interactions with things at any moment.

Harman et al. (2011: 651)

Memory is often opposed to materiality. Where memory is seen as variable and open to change over time, the material world is understood as consisting of an unchanging substance vulnerable only to perception. But the remembered object is not simply the object of memory - it does not always stand apart from the memory of it or the embodied remembering subject but helps to produce both memory and subject. Material remembering is therefore a provocation to question the substantiality of the material and the seeming insubstantiality of memory. This article explores the ways in which memory and materiality are better understood as intertwined producers of memory effects, some particularly marked by our ideas of 'past' and the productions of 'history'. To appreciate memory as an effect experienced through and with materiality is to understand materiality per Law (2008) as 'a continuously enacted relational effect' (p. 61). To think memory as also material, and so as memory effects, provides us with a more telling idea of why memory constantly exceeds any easy division

\section{Corresponding author:}

Katrina Schlunke, Cultural Studies Group, Arts and Social Sciences, University of Technology, Sydney, PO Box I23, Broadway, Sydney, NSW 2007, Australia.

Email: Katrina.schlunke@uts.edu.au 
between individual and collective and between the unconscious and conscious - for 'effects' are not divisible into any binary nor curtailed by any linear order of time.

Memory effects will be explored through two objects, one very small and one very large. The first is a box of Redhead matches with a reproduction of the painting 'The Landing of Captain Cook at Botany Bay' on its cover that circulated in the 1970s and again now and the second is the giant ('Big') Captain Cook at Cairns. The physical production of Cook in both echoes back to earlier images and earlier 'structures of feeling', which produced Cook as benign and white. But these things also push us forward into modes of capitalist consumption and perhaps sideways or other ways into their effectivity as things around which time and notions of 'national' memory whirl and eddy. ${ }^{1}$ Through a material remembering the reproduction and change in how memory works as minor and major effects is revealed to suggest a new arrangement for figuring what memory is.

\section{Story I: The Small Cook}

I am holding in my hand a box of matches. Resting between my thumb and forefinger, I begin to slightly push and pull the box within the box, making the matches slide back and forth ever so slightly. Is it memory, habit, design or something we might call 'the box itself' that sets off this fiddling, this pleasurable translation from still object to a kind of animate toy, something that does something. I become more aware of being surveilled. It is the usual hesitancy about being seen to be 'handling matches' without purpose - a childish reflex about being seen to be 'playing' with matches. In Australia, this is an expression particularly loaded with possibilities that combine delinquency, the devastating conflagrations of high summer bush fire and the pleasures of play. Careful to avoid contact with the striking paper, careful to keep its dry usefulness untainted by my sweaty palms I look. Already, I am not behaving as one should with an ordinary box of matches. Taken up and opened, match extracted, match struck and the box flicked or placed back in place - this is the sharp performance of 'striking a light'. With memory, that striking, that flare is the moment of action and production where we - Genesis like - god like - make light. All that power and more is in this box, and therefore to look rather than act is peculiar, and the covers of matchboxes with only seconds to catch our attention are usually bold and simple, but this one is thick with detail. This is the writing from top to bottom: Average 50 Safety Matches, then the brand title in bold - REDHEADS - and then in very small print, the subtitle of the $2.5 \times 2.5$ image - Co Landing Botany Bay, 1770 (Image 1). Then, below that, ' 60 years' and then there is 'More than Just Matches'. The subtitle of the image is cut across by the swirl of the stylized red hair of the Redhead match figurine, but we know that 'Cook' is what the hair hides: 'Cook Landing, Botany Bay, 1770'.

The image is a kind of militarized and miniaturized caricature of E. Phillips Fox's painting, 'Landing of Captain Cook at Botany Bay, 1770'. Unlike the original painting that has two Indigenous men armed with shield and spears at a distance, this version has a single threatening Indigenous man, arms raised, spear poised who effectively becomes the focus of the group. This comes about because of the miniaturization where the background and foreground have been pressed together. Without Cook's overwhelming centrality in the Fox painting, this scene becomes a scene of battle; the crouching marine and ordinary sailors responding to a 'clear and present danger' of a (relatively) giant Indigenous warrior. Cook becomes a figure $1.5 \mathrm{~cm}$ tall from toe to hat, a figure that I can cover with one finger. Cook has his right hand bent and rather lazily points off to the left, and his head turns to us, the viewer, as if he might be about to comment on the scene. 


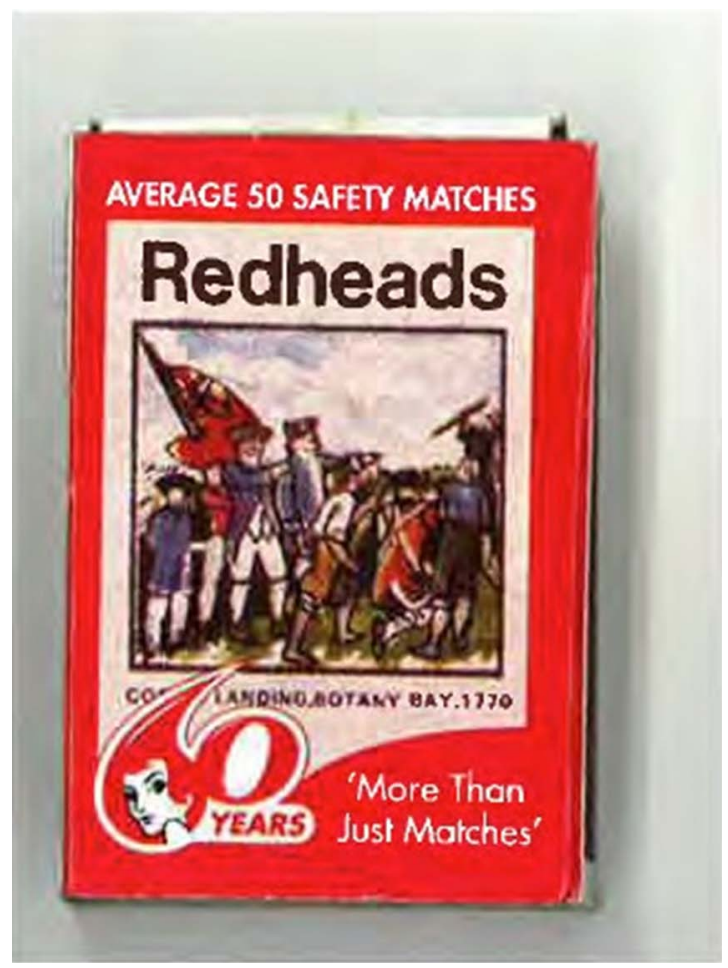

Image I. Story I - the small Cook.

It would be easy to let go of the box, let go of the 'object' and see this small image as the box but that is exactly where I would like to make the case for memory effects. The box, the hand, the image, the holding and the reading is an assemblage that produces many effects and one of the temporally infused effects is a memory effect. 'Not strictly separable from either history or representation' writes Michael Rothberg (2009), 'memory nonetheless captures simultaneously the individual, embodied and lived side and the collective, social and constructed side of our relations to the past' (p. 4). The simultaneity that Rothberg artfully evokes here conceives of memory as both experience and representation. And we know through all the structural work done with language that when something is re-presented something is (partially) lost, and yet, those constructions are often one part of the embodied experience of memory. Here, this small object and even smaller image are able to produce an effect of touching Cook, covering Cook through both representation and the experience of that boxed representation. Its size matters. In her chapter on the miniature, Susan Stewart (1999) writes, 'The miniature does not attach itself to lived historical time', and in the same section she continues, "The reduction in scale which the miniature presents skews the time and space relations of the everyday lifeworld, and as an object consumed, the miniature finds its "use value" transformed into the infinite time of reverie' (p. 65).

Perhaps the mass manufactured version of that experience is the anxiety about losing or displacing this particular box, this particular Cook box because it is only with this one that we can play with Cook. In this more playful reverie, we can turn him on his head, cover him, look into the tableau like a minute television and see other possibilities. In this minor frolic, Cook is no longer doing the national historic work of being an iconic and untouchable symbol of colonial control, of 
imperial 'discovery', even as this box at this scale is doing the intimate and pervasive work of inserting Cook within the familiar flows of minor commodities.

Following Stewart, it seems true that the work of this box of matches comes a little unstuck with the addition of this memory work - we look too long at the box itself, we fiddle and forget to light matches. As a kind of material remembering, the miniature Cook produces a set of effects that sees us holding a box about to strike (a light), that has on its cover an angry Indigenous man, (an Eora warrior) also about to strike - Captain Cook depicted as the coming white light. What to call the possibility of this simultaneity? What is this acting with and through the box - this acting of the box and its image on me - doing to make memory otherwise? Displacing humancentred consciousness as the only source of memory making, and making a small space for the multiple effects of the box and its miniaturization may enable us to see the utter liveliness of memory. This is memory as a series of memory effects that produce a spark of interested connection that re-enchants the relationship of 'us' and 'things' within time. The position of the box of matches as one part of the global flow of products means that Cook on this box is simultaneously inscribed into the ordinary - what can pass as 'common' to a Swedish product seeking an Australian market - and yet through miniaturization produces new and renewing translations of the past and experiences of the present.

The box is doing memory and memorializing work in other ways. At base, this box is a re-print of the 1970 Series called 'Captain Cook'. The images included on those boxes in 1970 (the anniversary of Cook's year of arrival in Australia) included individual portraits of Captain Cook, Joseph Banks and William Hodges, images of his statue, Captain Cook's Cottage, the Endeavour, maps of voyages, the canon from the Endeavour and scenes titled 'Hostile Botany Bay Natives' and 'Captain Cook's Death in Hawaii'. That list of images suggests the popular cacophony in which Cook circulates at a national level - he is both made known and known for being known. His portrait is circulated but so are pictures of invented Cook sites like Captain Cook's cottage in Melbourne and his statue in Hyde Park. This doubled seriality of Cook, as both a set of things and sites and a mass produced figure on a mass produced matchbox, offers us an order of exhaustion with memory itself. How can we re-member when he is always present? Does this not challenge memory to properly account for how Cook 'stuff' works?

\section{Story 2: the Big Cook}

I (and my partner) am staying at the Captain Cook backpackers in Cairns - one part of the inexhaustible experience of researching Cook in the popular Australian imagination. This is a slice of life that suggests something of a tinged sense of the different world of carnival people. It is the giant Captain Cook outside that shelters and distorts the world of the backpackers camped within his compound (Image 2). In various lights, he can appear grandly tatty, but still with a hint of noblesse oblige and in another light, his outstretched hand looks like a Hitler salute (or the giant of Lilliput) that is striding across the world in some fearful war of the worlds. But from within 'Cookies Bar' and the beaten-up rooms, he looks most of all weirdly ridiculous. There is a sense in which his size spreads our squalidness. And what is this squalor? For almost everyone here, it is not squalor at all but cheap and cheerful and familiar. Only someone over 40 notices that this was once an upmarket 1960s motel gone seriously, ruinously to seed. For the 18- to 25-year-olds, this is fun and they know what to expect.

The bits and pieces here and there mark it out as some place where young people have a good time. Arriving at near 12 midday, the office is shut until 3 p.m. (for siesta), and therefore, we are sent by our pick-up mini-bus driver who only works weekends to the 'poolside TV room' to wait. The poolside TV room is a shed next to a small pool with a near destroyed vinyl couch and two 


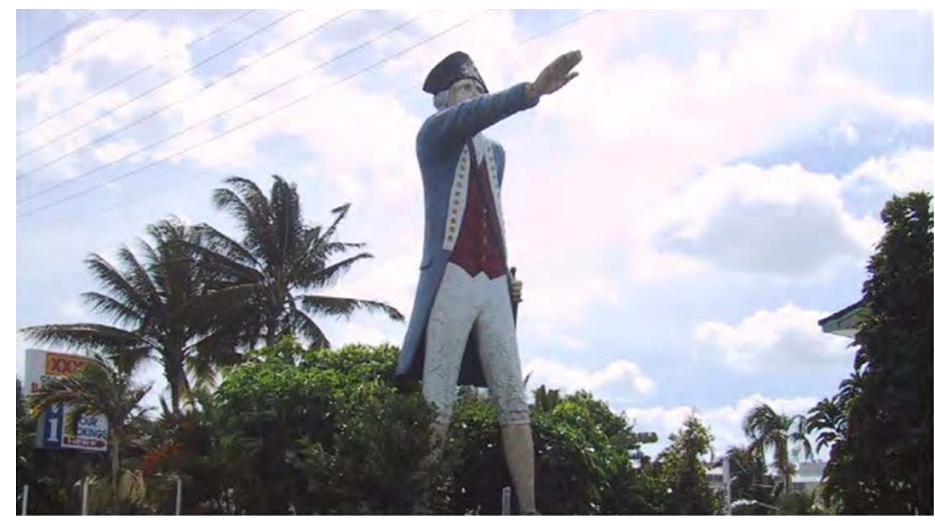

Image 2. Story 2 - the very big Cook.

Source: Cairns. 2005. Captain Cook Backpackers.

traumatized chairs facing a TV in a wooden security box - a face-off courted by a coke machine to the side that maintains a loud continuous hum. We are weary and so for quite a while we stretch ourselves over the exposed skeleton of the couch and watch Australian Broadcasting Cooperation (ABC) documentaries, which seem to be the only offering. We see an 'Australia Story' about the man who started 'Voiceless', an animal rights group, and then something about magic healing practices in South Africa, but even buggered and in this new sleepy tropical warmth, two hours is enough, and we do not wait to find out what happened to the ecological system of a small Nigerian lake. We go off for a painful walk. We stop and properly admire Big Cook.

He looks crumbly and roughly hewn and way too thin and sinewy. But his hand is still raised in that Jesus-like, all-will-be-known, explorer way. The image of Cook began with the Fox painting of Cook's landing. But surely this hand is higher? Definitely more Hitler than Fox. His other hand clutches a sword. We walk on to the city and come back in a cab and finally get access to our room. Small orders of motel life are reversed. Our room includes a dinner of spaghetti and salad but no breakfast. Our room has a small safe but no working air conditioner. Our room has a state-of-the-art television and cable service with seven channels but no room service. Most of all, it feels like a crime scene. Battered doors, a small en-suite with a sliding door that does not close, fluorescent lighting in rusted cases, counters covered in 1970s Laminex that is peeling back to show screws and broken chipboard crumbling out its invisible greenhouse gases. For a room quite away from the pool, it smells of chlorine, and when we lie down for a siesta, we are flooded with diesel fumes as one vehicle after another leaves - noisy as hell and that strange oily smell that sticks. There is something like battery acid coming out of the electrical socket in the bathroom, and the switch in the main room flicks sparks when we put the kettle on. But there is a luggage rack. A point to motel designers - luggage racks last. Ours is barely decayed and seems to be made of solid wood - in case of flood stick to your luggage rack. The mattresses are bad but not unbearable, and the beds are of that tubular frame that you connect to a child's room. This mix of childhood and chaotic adulthood, of being on a camp and in sheltered accommodation, is reinforced by the sudden boom of the public address system asking for Kelly Bryant to come to reception. And of course, a public address system for there is no individual room phone system, and this simple communalism has an easygoing appeal. When we meet this couple-pocketed mass of young folk, they are sweet and lively and mostly English or Irish and have had jobs picking fruits and in call centres and have a commitment to seeing Australia from the lower end of the service industries with a bit of rural labour thrown in.

When we eat together that night - bolognaise with tasty cheese, the kind of food you cook for kids - we find the tattooed cook at Cookies is one of those cooks that makes jokes and kind of 
flirts when my partner asks for 'a bit of everything'. Cook is another kind of amusing irrelevancy here, a weak joke - all washed up. He does not compete for one second with extreme skydiving and reef-to-rainforest adventures. Cook is quite at home here. We are all young British salts together. Pass the rum, behave badly, be forgiven, arrive back at Cook in your mini-bus Endeavour, and one day really go home. And mostly, the British backpackers (BBs) do follow Cook's route. They land in Sydney and head north, seeking safe landings that they know through half-secret maps from new Internet acquaintances.

Much later, long after we have returned, there is a news story that Big Cook is for sale. The backpackers hostel is being re-developed. Students at James Cook University want it for their campus, but the vice chancellor while impressed with the students' proposal and by their enthusiasm says, 'I'm not sure that the statue would fit in too well with the campus. When you look around the campus its absolutely beautiful, its right in the rainforest. I'm not sure the statue would fit in' (ABC, 2006). I guess, he thinks Cook is unnatural and ugly. The newspapers print old Queensland yarns about how this Cook was meant to be a mascot for the bar but that in the conversion to metric from imperial measure, they ended up with this mistaken giant. We keep an eye on progress. I go to hear Dawn Casey, former Director of the National Museum of Australia. She was removed in the Howard years after completing this museum 'on time and under budget'. Pat Dodson (former Chairman of the Council for Aboriginal Reconciliation) famously said she was removed because she was not White and she did not have a dick. ${ }^{2}$ She said, '... we've been raised on Captain Cook only'. I think give them Captain Cook. Serious Cook. A monster Cook gone to seed. Let us stage our first Australian ruin, watch Cook flake to metal aperture somewhere between the Australian Institute of Aboriginal and Torres Strait Islander Studies building and the muddy shore of Lake Burley Griffith, where the Australian Museum that Dawn Casey was removed from sits. Somewhere between those buildings and those shores in the heart of the Australian national capital must be the perfect place to stage another and final death of Cook. I ring the National Museum of Australia collections curator. She seems surprisingly keen. I send an email. She asks for more details. I make a small case. I reassure her that it is free barring the removal costs. I imagine a felled Cook on the back of a truck being carried back down the east coast of Australia, everyone able to chip off a piece in revenge or curiosity and then the tiny remains put on permanent display outside new Parliament House so we might never forget the scale of white presence compared to black in this nation. I imagine this weary Cook's arm slowly falling and coming to rest half submerged in the lake next to the museum. I hear back from the museum. 'No, I'm sorry to say that despite all the Committee decided they would not investigate acquiring the item'. Years later, now, he is still standing but now over an entirely empty paddock.

This gigantic Cook has a frightening pedigree in European mythology. As Stewart (1999) writes, 'The giant, from Leviathan to the sideshow freak, is a mixed category; a violator of boundary and rule; an overabundance of the natural and hence an affront to cultural systems' (p. 72). The giant is also, according to Stewart, associated with the foundational myths of both cities and landscapes. With all these associations and with Cook still read as the founder of white invasion in Australia, this tatty monster should surely be understood as a frightening overreaching of a white supremacist imagination, but this does not appear to be the case, at least in found non-Indigenous critique. As Stockwell and Carlisle (2003) write,

... it could be argued that big thing(s) function to both signpost white history and subvert it at the same time: the Big Ned Kelly calling for revolution, the big goldminer looking ever expectant and ever disappointed, the Big Captain Cook in Cairns giving what appears to be a Nazi salute, all point to a larrikin refusal to take the brief and minor white history too seriously. (p. 1) 
This is a tricky ground for memory. Is it true that an inflated invader (with 'a Nazi salute') becomes a memorial to a shared acceptance by black and white Australians that the 'brief' (and violent?) white history should not be taken seriously? And not taken seriously up north where violence towards Indigenous peoples followed through all the major government processes from massacre to mass removals? As a giant, this Cook is dangerous but as a 'Big Thing' ${ }^{3}$ amid a collection of other big things that dot the rural Australian landscape, perhaps he is not. Or perhaps he is both. Barcan (1996) seems to suggest that some Big Things do have some role in history making. She writes that amid so many Big Things dedicated to the natural or agricultural world (the Big Banana, the Big Pineapple) '[o]ne or two historical Big Things wrest the business of history-making away from the realms of public statues and serious monuments ...' (Barcan, 1996: 31). Big Cook is not a 'serious monument' but perhaps produces a powerful memory or memory effect through his affective materiality. Stewart makes the case that the power of the natural giant has been lost in the invention of modern behemoths that advertise peas and disinfectant and that speak only of the product they espouse. But perhaps memory-making Big Things do something more. In 'Big Cook', both the gigantic force of modern industry and capital join with the origins of that power in this country - colonialism - to make of this 'thing' a creature both magical and modern. And now that Big Cook is old and crumbling, producing effects we no longer want, I join with another tradition of wanting to fell the giant.

Do these things matter for memory? 'Cook' seems to work best through things. It is as if they rush toward him. James Cook was a man who undertook a particular journey for a set of varied purposes: military, scientific, personal and political. He became in Australia, Captain Cook, a figure, variously remembered and forgotten through national political imaginings and integrated into everyday life via modes of consumption, geographical namings and ordinary activities. In this sense, Cook is a marker both of the most violent and unresolved tremors in our national imagining and of our banal everydayness. That is, Cook reminds us and is bound into national thinking around Indigenous Sovereignty, immigrant arrival and ideas of environmental and scientific development, and he is also known to us as Captain Cook who chased a chook, as a Bunnykins statuette, as the name on hundreds of streets, parks and rivers and seen fleetingly on matchbox covers. Up north, we can even eat him in the shape of the Captain Cooker pig. There are as Paddy Wainburranga, a key Indigenous Elder, said so presciently 'too many Captain Cooks'.

This expression 'Too many Captain Cooks' comes from one of the many Indigenous moral fables about Cook. They tell us that the power of Cook and all the Cooks that came after him - people like me - works through the replication and proliferation of people who refuse to obey the Indigenous laws of this country. But there is another order to this proliferation. With Captain Cook, you can never look at things from afar. You always find yourself buried or swimming through him. Coca Cola trays, beer brands, pub names, convenience stores, drawings on fur, games, names, places, stories, memories, claims to history, philosophy, politics, micro and macro, the removal of heads of museums, maps, murals in pubs, cups of tea, rum, a sea and the responses of ordinary people finding something to say to me. The pleasures and mess of the popular. The effects of the matter that assure us of the fact of Cook's ordinariness, his material certainty. Mattereffect. Mattereffect is a sound trying to be a word that might work to describe this mix of stuff and sensation. Those word sounds, mattereffect, mattereffect, might show the rub that remains after fact and within effect and matter. Like grubbing through rubbish for something that promises a new kind of use, what kind of memory thinking could come from all this ooze that squeezes out of Cook? 


\section{Cook's memory}

Memory does not seem to work in this necessary register of 'stuff' and of being 'in stuff'. The order of memory associated with Cook seems both too banal and precarious (a matchbox), and too preposterous (a Big Cook) to quite fit within even Rothberg's expansive definition. Yes, our response to these Cook things is both embodied and a process of representation but is it only that? It is, I would argue, an experience that should not be conceived of as containing separate humancentred aspects, corporeal or imaged, but rather one in which the affectiveness and contingency of these things can be seen as memory effects busily staging further connections, further acts of translation. Cook is an historical figure, but he is also a popular figure - and he is both at the same time. The 1902 painting by Fox was one translation of Cook's original arrival at Botany Bay that produced through its viral national circulation a particular order of effects that could still be called (contingently) 'national memory', but one not arising from human consciousness alone but rather from the powerfully indeterminate effects of time and matter.

What is memory here? Memory is at work through memorialization in the efforts of the Redhead Matches Company to mark their 60th anniversary with a re-release of their '1970 Series', which includes the reproduction of the box with the image 'Cook Landing Botany Bay 1770'. But memory is also at work in sleeping in a bed in an ex-motel near Big Cook that reminds me of other bad motels. But is not memory also there in the habit of flicking the matchbox, the feeling of being too old for that backpackers hostel? As Harman (2010) writes, 'Instead of memory being an internal mental engine that cooks and mixes left-over perceptions, perception is redefined as a form of cosmic memory, as an instrument for gathering information emitted by a past reality already dead' (p. 588). Here perception is memory - not a relayed or represented after-effect but a way in which meaning is experienced. I baulk at 'cosmic' but that perception is already memory seems a neat account of how things connect with other things and with people and parts of people. But how might that work in the particular?

What work does Cook do in the nation and how does he do it? (And is 'work' quite the right word for what Cook 'does'?) That he operates in some way through memory seems clear given he is not 'really' alive and given the order of continuous and official memorialization he performs in Australia and elsewhere. But he also works through 'things'. Mobile objects like 'Captain Cook Cruises', sites of day-to-day consumption like the 'Captain Cook Convenience Stores', museum freighted things like the replica of the Endeavour and this matchbox and this big thing. Is it that we look at these things and arrive at an understanding of them in association with a known set of further Cook things (his violent landing at Botany Bay, the pacifying painting, the edited journals, etc.) and thus arrive at a 'collective' memory that will also be our individual 'memory' of these things or do these things come at us? Do they enact their own order of memory in our very perception of them?

To perceive Cook as 'small' and 'big' is to open paths of perception and connection that may better account for the circulations and translations of memory. To think of memory as having a scale is to see memory as always simultaneously physical and temporal. These are memory effects. To think memory as memory effects is to give memory a key place not just in orders of concatenating events that we may over-determine as 'national' but as an order of perception given to us by the things themselves. As a set of memory effects, Cook is both strange and known, banal and monsterish and always within an order of indeterminate materiality. Memory is more than consciousness, and understanding Cook as very small and very large lets us see very performatively the things we take for granted in the making of memory.

\section{Declaration of conflicting interests}

The author declares that there is no conflict of interest. 


\section{Notes}

1. Harman (2009) writes that Latour's 'We Have Never Been Modern' suggests that we 'cannot say that time passes in terms of irreversible revolutions, but only that it whirls and eddies according to shifts in the network of actants' (p. 68). This is a fruitful notion for time but perhaps less nuanced in its appreciation of the effects of 'memory' as also a powerful actant that like land or mining can as a cultural assemblage whip up storms of violence and nation-ness.

2. Quotes from the The Songlines Conversation first broadcast Sunday July 2006. Transcript available at: http://www.abc.net.au/radionational/programs/bigideas/the-songlines-conversations-dawncasey/3323368\#transcript (accessed 13 November).

3. There is a tradition since the 1970s in Australia of the 'big thing'. These are usually established within some order of tourist discourse, are usually of a vegetable or animal variety and now have their own kitsch cultures surrounding them. The most famous are the Big Pineapple and the Big Banana.

\section{References}

Australian Broadcasting Commission (ABC) (2006) Captain Cook to set sail into the sunset. $A B C, 27$ February. Available at: http://www.abc.net.au/farnorth/topics/features.htm (accessed 2 April 2013).

Barcan R (1996) Big things: consumer totemism and serial monumentality. LiNQ 23(2): 31-39. Available at: http://search.informit.com.au.ezproxy.lib.uts.edu.au/fullText; $\mathrm{dn}=970707180 ;$ res=APAFT (accessed 18 September 2012).

Frow J (2010) Matter and materialism: a brief pre-history of the present. In: Bennett $\mathrm{T}$ and Joyce P (eds) Material Powers: Cultural Studies, History and the Material Turn. London: Routledge, pp. 25-37.

Harman G (2009) Prince of Networks: Bruno Latour and Metaphysics. Melbourne, VIC, Australia: re.press. Harman G (2010) Towards Speculative Realism: Essays and Lectures. London: John Hunt Publishing (Kindle Version).

Harman G, Latour B and Erdely P (2011) The Prince and the Wolf: Latour and Harman at the LSE. Zero Books: London.

Law J (2008) After Method: Mess in Social Science Research. New York: Routledge.

Rothberg M (2009) Multidirectional Memory: Remembering the Holocaust in the Age of Decolonization. Stanford, CA: Stanford University Press.

Stewart S (1999) On Longing: Narratives of the Miniature, the Gigantic, the Souvenir, the Collection. Durham, NC: Duke University Press.

Stockwell S and Carlisle B (2003) Big things: larrikinism, low art and the land. M/C: A Journal of Media and Culture 6(5). Available at: http://journal.media-culture.org.au/0311/6-stockwell-carlisle-big-things.php

\section{Author biography}

Katrina Schlunke teaches cultural studies at the University of Technology, Sydney, and is a member of both the Cultural Materialities and the Intimacies research programmes within the Transforming Cultures Research Centre. She is a co-editor of the Cultural Studies Review, and she is currently completing a monograph on the cultural uses of Captain Cook tentatively titled Discovering Possession Island. 